\title{
Ofiyolitler İçerisindeki Gabro Dayklarının Balast Malzemesi Olarak Kullanılabilirliği: İnceler (Bozkurt-Denizli) Örneği
}

\author{
Tamer KORALAY ${ }^{1}$, İbrahim ÇOBANOĞLU ${ }^{1}$, Mevlüt DEMIIR ${ }^{2}$ \\ ${ }^{1}$ Pamukkale Üniversitesi, Jeoloji Mühendisliği, Denizli, Türkiye \\ ${ }^{2}$ Pamukkale Üniversitesi, Jeoloji Mühendisliği Ana Bilim Dalı, Denizli, Türkiye
}

\begin{abstract}
ÖZET: Balast, demiryollarında ray altında kullanılan, yüzey suyunu ortamdan uzaklaştıran ve yük taşıyan bir malzeme olup, $30 \mathrm{~mm}$ ila $60 \mathrm{~mm}$ çapında köşeli ve yeterli sertlikteki taşların (bazalt, granit, siyenit, diyorit, diyabaz) kırılması ile elde edilen agrega malzemesidir. Bu makalede ofiyolitik kayaçlar içerisindeki gabro bileşimli daykların balast malzemesi olarak kullanılabilirliği araştırılmıștır. Bozkurt (Denizli) ilçesinin G'inde yeralan Üst Kretase yaşlı Yeşilova ofiyoliti içerisindeki gabro daykları holokristalen tanesel, subofitik dokuya sahip olup, mineralojik olarak plajiyoklaz (labrador) + piroksen (ojit) + amfibol(aktinolit-tremolit) + Fe-Ti oksit (ilmenit, manyetit), klorit, sfen, prehnit, manyezit \pm kalıntı olivin ve \pm serpantin minerallerinden oluşmaktadır. Gabro daykları toleyitik karakterli olup, hesaplanan ayrışma indeks değerlerine göre çok hafif derecede ayrışmış kaya özelliği gösterdikleri belirlenmiştir. Gabro örnekleri üzerinde yapılan fiziko-mekanik test sonuçlarına göre kayaçların birim hacim ağırlıklarının $2.63-2.81 \mathrm{gr} / \mathrm{cm} 3$, ağılıkça su emme değerlerinin $\% 0.05-0.52$, tek eksenli sıkışma dayanımlarının ise kuru koşulda $84.66 \mathrm{MPa}$ - 134.66 MPa değerleri arasında, suya doygun koşulda ise $67.69 \mathrm{MPa}-144.32 \mathrm{MPa}$ değerleri arasında değişmektedir. Mineralojik, petrografik, jeokimyasal ve fiziko-mekanik inceleme sonuçlarına göre; gabro örneklerinin balast malzemesi olarak kullanılabilirlik nitelikte olduğu belirlenmiştir.
\end{abstract}

Anahtar Kelimeler: Ofiyolit, Gabro, Balast Malzemesi, Ayrışma İndeksleri, Fiziko-Meokanik Özellikler

\section{Usability of Gabbro Dikes within The Ophiolitic Rocks as Ballast Aggregate: İnceler (Bozkurt-Denizli) Case Study}

\begin{abstract}
Ballast is aggregate materials is a material bearing the burden of the railways and removes the surface water from the environment. They are used under railways and consist of angular rock fragments (basalt, granite, syenite, diorite, diabase) which has $30-60 \mathrm{~mm}$ in grain size and sufficient hardness. In this paper, usability of gabbro dikes, cross-cutting the ophiolitic rocks were investigated as ballast aggregate. Approximately $15 \mathrm{~km} \mathrm{~S}$ of Bozkurt (Denizli) town, Upper Cretaceous Yeşilova Ophiolite is cross-cut by gabbro dikes. In microscopic investigations, Gabbro dikes have holocrystalline granular and/or subophitic texture and consist of plagioclase (labradorite) + pyroxene (augite) + amphibole (actinolite-tremolite) + Fe-Ti oxides (ilmenite, magnetite), chlorite, sphene, prehnite, magnesite \pm relict olivine and \pm serpentine mineral. According to the calculated weathering index values, gabbro dikes which are tholeiitic character, exhibit very slightly weathered rock. According to physical test results of gabbro samples, unit weights and water absorption values are ranging between $2.63-2.81 \mathrm{gr} / \mathrm{cm} 3$ and $0.05-0.52 \%$ respectively. In strength point of view, unconfined compression strength in dry and saturated conditions is obtained as $84.66 \mathrm{MPa}-134.66 \mathrm{MPa}$ and $67.69 \mathrm{MPa}-144.32 \mathrm{MPa}$ respectively. In the light of mineralogical, petrological, geochemical and physico-mechanical test results, gabbro samples meet the values therefore can be used as ballast material.
\end{abstract}

Keywords: Ophiolite, Gabbro, Ballast Materials, Weathering Index, Physico-Mechanical Properties

\section{GÍRIŞ}

Artan yolcu ve yük taşımacılı̆̆ının çözümünde demiryollarının en ekonomik ve en güvenilir işletme sistemi olduğu bir dünya gerçeğidir. Ülkeler gelecekteki yolcu ve yük taşımacıllğının planlamasını yaparken, mevcut demiryollarını bilim ve teknolojinin gerektirdiği biçimde tasarlamalıdırlar. Son yıllarda demiryollarının ülke politikamız olarak yeniden ele alınması yeni demiryolu hatlarının yapılması ve mevcut demiryollarımızın günümüz teknolojisinin gerektirdiği biçimde yenilenmesi sonucunu doğurmuştur.

Demiryolu hatlarımızı oluşturan malzemelerin (ray, balast gibi) günümüz teknolojisine göre kalitesiz ve 
yetersiz kalması, yol güvenliğini önemli ölçüde tehdit etmektedir. Bilindiği gibi demiryolu ulaşımında traversler tarafından iletilen tüm etkileri kalıcı çökmelere uğramadan zemine ileten ve yol çerçevesinde elastik bir yatak oluşturan; 30-60 mm ebadında kırılmış, keskin köşeli ve keskin kenarlı sert ve sağlam kayaçlara balast denir. Balast, demiryollarında ray altında kullanılan, yüzey suyunu ortamdan uzaklaştıran ve yük taşıyan bir malzemedir. Geçmiş yıllarda balast malzemesi olarak kullanılan kireçtaşı türevli kayaçların etkisi altında kaldıkları atmosferik olaylar ve tren yüklerinden kaynaklı olarak zamanla özelliklerini kaybettikleri görülmüştür. Ekonomik anlamda büyük yatırımlar gerektiren bu tür projelerde kullanılan doğal taşların uygun standartlara sahip olup olmadığının araştırılması ve uygun malzemelerin seçimi büyük önem taşımaktadır. Hat yapımında kullanılacak kayaçların mineralojik ve petrografik özelliklerinin yanında fiziko-mekanik özelliklerinin detaylı olarak araştırılması gerekmektedir. Bununla birlikte uygun standartlara sahip kayaçların arazideki dağılımları ve rezerv durumları, ocak işletme yöntemleri seçimi gibi konularda ayrı bir önem taşımaktadır.

Bu çalışmanın amacı Yeşilova ofiyoliti içerisindeki gabro dayklarının mineralojik bileşimlerini, dokusaljeokimyasal özelliklerini ve ayrışma indislerini belirlemek, standartlarda önerilen fiziko-mekanik test sonuçlarına göre demiryolu hat inşasında balast agregas olarak kullanılıp kullanılamayacağını araştırmaktır. Bu amaçla; Denizli ili Bozkurt ilçesi, İnceler beldesinde bulunan taş ocağı uygulama alanı olarak seçilmiş, parça ve blok boyutlu örnekler alınmıştır.

\section{MATERYAL ve METOT}

Gabro örneklerinin mineralojik bileşim ve dokusal özelliklerini belirlemek için incekesitler hazırlanmıştır. Mineralojik ve petrografik incelemeler Pamukkale Üniversitesi Jeoloji Mühendisliği Bölümü Optik Mineraloji Laboratuvarında, "Leica DMEP marka polarize mikroskop" kullanılarak yapılmıştır.

Gabro örneklerinde optik mikroskop çalışmaları sırasında belirlenemeyen daha küçük boyutlu bileşenleri belirleyebilmek için X-Işınları Difraktometre (XRD) analizleri yapılmıştır. XRD analizler için, farklı gabro dayklarından alınan 6 adet kayaç örneği, halkalı değirmende 150-200 mesh boyutuna kadar öğütülerek toz haline getirilmiştir. Toz halindeki kayaç örneklerinin XRD analizler Ankara Üniversitesi Jeoloji Mühendisliği Bölümü Mineraloji ve Petrografi Araştırma Laboratuvarında "Inel Equinox 1000" marka cihazla kobalt katotlu tüp kullanılarak yapılmıştır.

XRD analizleri yapılan gabro örneklerinin kimyasal analizleri Pamukkale Üniversitesi Jeoloji Mühendisliği Bölümü XRF Laboratuvarı'nda Spectro XEPOS-III PEDXRF cihazı kullanılarak yapılmıştır. Analizler
USGS'in volkanik kayaçlar (bazalt, andezit) için oluşturduğu standartlar kullanılarak kalibre edilmiştir. XRF analizleri için, gabro örnekleri halkalı değirmende 150-200 mesh boyutuna kadar öğütülmüştür. Elde edilen kayaç tozları 1100 oC'lik firında 2 saat kalsine edilerek, örnek ağırlığının yüzde azalımı olarak hesaplanan kızdırma kaybı miktarları belirlenmiştir. Daha sonra her bir kayaç tozundan 6.25 gr alınarak, 1.40 gr bağlayıcı wax ile homojen bir şekilde karıştırılmıştır. Karışım halindeki örnek tozu 15-20 N/m basınç altında, $40 \mathrm{~mm}$ çapında bir tablet şeklinde sıkıştırılmış ve analize hazır hale getirilmiştir.

Gabro örneklerinin mekanik ve fiziksel parametrelerini belirleyebilmek için araziden blok şeklinde numuneler alınmıștır. Fiziksel ve mekanik özellikleri belirlemek için ISRM (2007)' de önerilen yöntemlere göre jeomekanik deneyler yapılmıştır. $\mathrm{Bu}$ deneylerde kullanılmak üzere blok numunelerden karot ve parça numuneler alınmıștır. Hazırlanan karot numuneler üzerinde birim hacim ağırlık, aşınma direnci, sodyum sülfata dayanıklılık, su emme ve basınç dayanımı deneyleri yapılmıştır. Deneyler Pamukkale Üniversitesi Jeoloji Mühendisliği Bölümü Kaya ve Zemin Mekaniği Laboratuvarında gerçekleştirilmiştir.

\section{INCELEME ALANININ KONUMU ve JEOLOJIK YAPISI}

Çalışmanın konusunu olușturan gabro daykları Bozkurt (Denizli) İlçesine bağlı İnceler beldesi sınırları içerisinde, 1/25.000 ölçekli Denizli M23-d1 ve M23-d2 paftalarında yer almaktadır (Şekil 1a). Acıgöl'ün güney'inde bulunan inceleme alanında allokton, paraallokton ve neootokton konumlu jeolojik birimler bulunmaktadır. Kayaköy dolomiti, Yandağ kireçtaşları, İğdir metamorfitleri ve Yeşilova ofiyoliti allokton konumlu birimleri temsil ederken, Varsakyayla formasyonu ve Kireçtaşı üyesi paraallokton konumludur. Neootokton konumlu jeolojik birimleri; Çameli formasyonu ve konglomera, alüvyon yelpazesi çökelleri, birikinti konisi ile yamaç molozu oluşturmaktadır (Şekil 1b) $[1,2]$.

Kalın tabakalı dolomit ve dolomitik kireçtaşlarından oluşan Kayaköy dolomiti inceleme alanının tabanında bulunmaktadır. Sı ̆̆ karbonat şelf ortamında çökelmiş Kayaköy dolomiti [3] tarafından adlandırılmış olup, Üst Triyas-Liyas yaşlıdır. DoggerÜst Kretase yaşlı Yandağ kireçtaşları birimi Kayaköy dolomiti üzerinde uyumlu olarak görülmektedir. [1] tarafindan tanımlanan Yandağ Kireçtaşları farklı ortam koşullarında çökelmiş pembemsi gri, gri, koyu gri ve bej renkli, kalın orta tabakalı kireçtaşları ile kızıl renkli ince tabakalı çörtlerden oluşmaktadır. Sedimanter özelliğe sahip bu birimlerin üzerine tektonik dokanakla Üst Kretase yaşlı İğdir metamorfitleri ve Yeşilova ofiyoliti gelmektedir. 

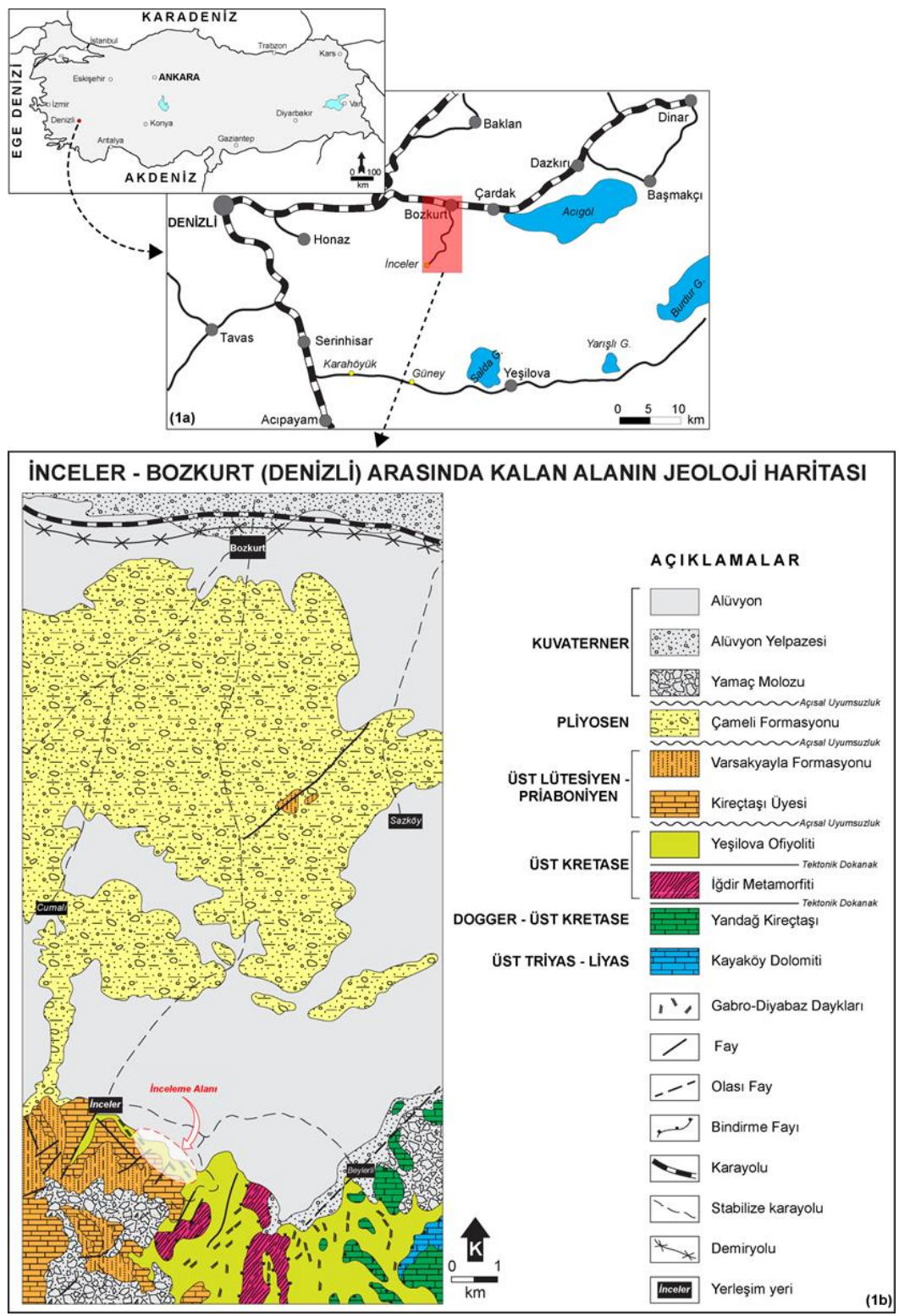

Şekil 1. a) İnceleme alanı yer bulduru, b) jeoloji haritası (Jeoloji haritası [2] değiştirilerek alınmıştır)

Garnet amfibolit, piroksen amfibolit, amfibolit, amfibol şist, mermer, kuvarsit, metabazalt türü kaya litolojilerinden oluşan İğdir metamorfitleri ilk defa [1] tarafindan adlandırılmıştır. Dolerit ve gabro bileşimli dayklar tarafindan kesilen İğdir metamorfitleri bazaltik kayaçlar ve ultramafik kümülatların yüksek sıcaklık-orta basınç koşullarında (amfibolit-yeşilşist fasiyesi) metamorfizmaya uğraması sonucu meydana gelmişlerdir $[4,5]$. İğdir metamorfitleri üzerine tektonik dokanakla ofiyolitik kayaçlar gelmektedir. İlk defa [6] tarafından Yeşilova ofiyoliti olarak adlandırılan birimin alttan üste doğru tektonitler, ultramafik ve mafik kümülatlar, izotrop gabrolar, plajiogranitler ve bazaltlardan oluşmuştur. Levha dayk kompleksi ve yastık lavların görülmediği Yeşilova ofiyoliti eksik dizi karakterli bir ofiyolit topluluğunu temsil etmektedir. Makalenin konusunu oluşturan gabro daykları harzburjit, dünit ve kromitlerden oluşan tektonitler içerisinde dayklar şeklinde görülmektedir (Şekil 1b) [1, 2, 7, 8, 9]. Allokton konumlu olan ve Likya napları olarak da tanımlanan bu birimlerin üzerine açısal uyumsuzluk ile Üst LütesiyenPriaboniyen yaşlı Varsakyayla formasyonuna ait kırıntılı ve karbonat kayaçları gelmektedir. [10] tarafindan tanımlanan Varsakyayla formasyonunun kırıntılı kayaçları genelde ofiyolitlerden türemiş konglomera, kumtaşı, kumlu kireçtaşlarından oluşmaktadır $[1,2]$. Orta-kalın tabakalı, sarımsı kahverengi renkli, bol mercan, pelecypoda ve nummulit fosili içeren kireçtaşı üyesi kırıntılı birimlerin üzerinde bulunmaktadır. Pliyosen yaşlı Çameli formasyonu konglomera, kumtaşı ve çamurtaşları ile gölsel karakterde kumtaşı, silttaşı, kiltaşı, marn, killi kireçtaşlarından oluşmaktadır. Kuvaterner yaşlı çökeller, çoğunlukla düzlüklerde görülmekle birlikte, yamaç molozu ve birikinti konisi olarak da gözlenmektedir [1, 11, 12, 13, 14, 15]. 


\section{GABRO DAYKLARININ ARAZİ ve PETROGRAFIKK ÖZELLIKLLRİ}

Ofiyoliti içerisinde görülen gabro daykları yeşilimsi gri renkte ve ince-orta $(100 \mu \mathrm{m}-2 \mathrm{~mm})$ kristalli yapıdadır. Kristal bileşenler çıplak gözle ve lupla kolaylıkla tanımlanabilmektedir. Topoğrafyada çıkıntı oluşturan gabrolar bol kırıklı ve çatlaklı bir yapı göstermektedir (Şekil 2a, b, c). Kırık hatları boyunca beyaz renkli prehnit, manyezit ve opal oluşumları karakteristiktir (Şekil 2d). Yeşilova Ofiyoliti içerisindeki harzburjit
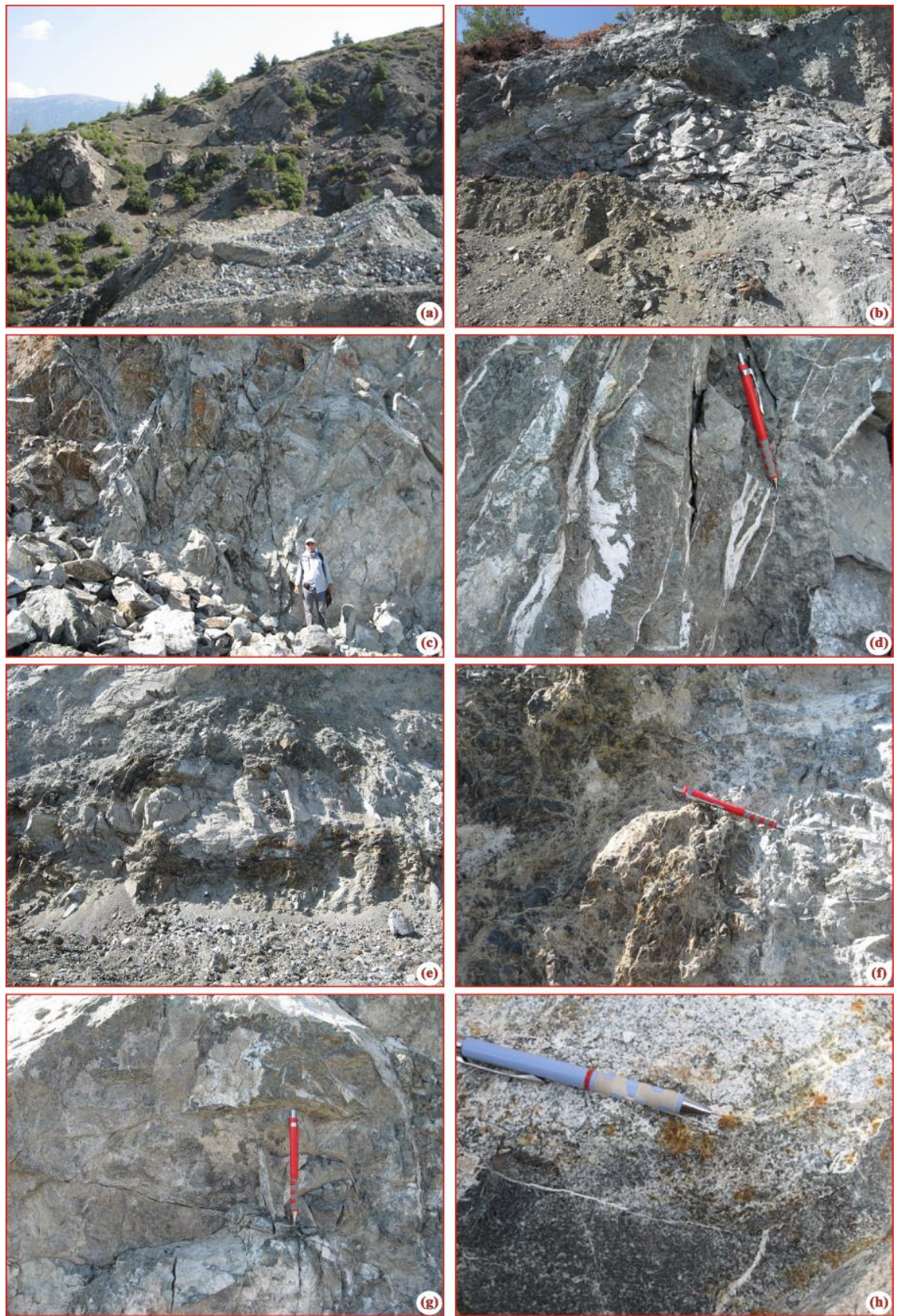

Şekil 2 İncelenen gabro dayklarının; a, b, c) arazideki görünümleri, d) gabro daykları içerisindeki kırık ve çatlaklarda manyezit ve opal oluşumları, e, f) gabro dayklarının kenar zonlarında görülen serpantinleşmiş zonlar, g, h) gabroları oluşturan plajiyoklaz ve piroksen minerallerinin yakından görünümü

bileşimli ultramafik kayaçlara sokulum yapmış olan gabro dayklarının kenar zonlarında yoğun serpantinleşmiş zon izlenmektedir. Bu zonun kalınlığ 1 ortalama 10-15 cm' dir. Dayk kenarlarında oluşmuş serpantinitlerde yaygın olarak elek (mesh) dokusu görülmektedir (Şekil 2e, f). Gabroların el örneklerinde plajiyoklaz ve piroksen minerallerinden oluştukları belirlenmiştir. Plajiyoklaz mineralleri beyaz, sarımsı beyaz renkli, özşekilsiz kristaller halinde olup, kumsu yapıda görülürler. Piroksen mineralleri yeşilimsi siyah renkte, özşekilsiz kristaller halinde görülürler (Şekil 2g, h).
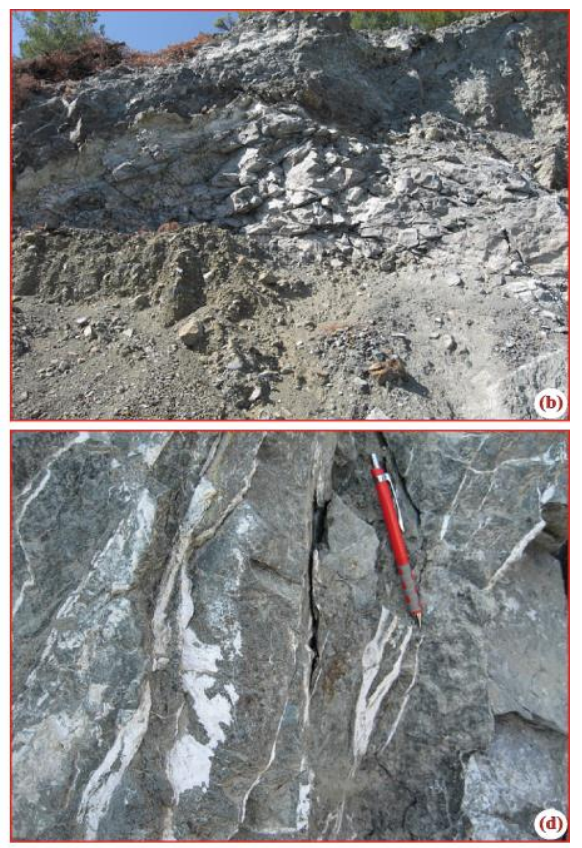

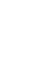



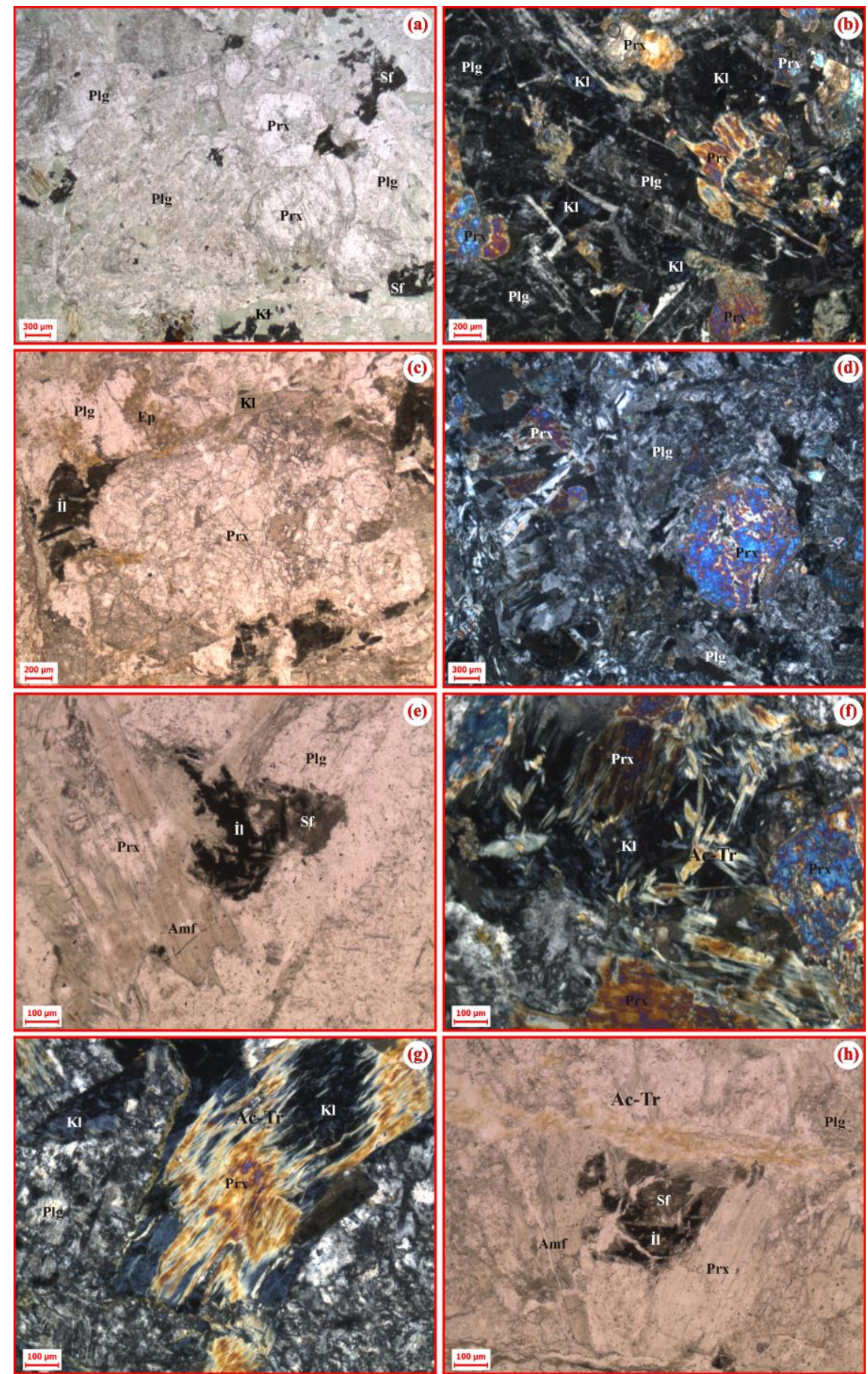

Şekil 3 Gabro örneklerinin mikroskop görüntüleri; a) plajiyoklaz minerallerinde görülen killeşme (I. nikol), b) plajiyoklaz minerallerinde görülen polisentetik ikizlenme (II.nikol), c, d) özşekilli piroksen minerali (I. ve II. nikol), e) uralitleşme sonucu amfibole dönüşmüș piroksen minerali (I. nikol), f) kloritleșme ve uralitleșme sonucu aktinolittremolit' e dönüşmüş piroksen minerali (II. nikol), g) kloritleşme ve kink-bant oluşumu gösteren piroksen (II. nikol), h) sfen ve ilmenit minerali (I.nikol)

Mikroskop incelemelerinde gabro örneklerinin tipik holokristalin tanesel, subofitik doku gösterdikleri ve plajiyoklaz, piroksen, amfibol, Fe-Ti oksit (ilmenit, manyetit), klorit, sfen, prehnit, manyezit \pm kalıntı olivin ve \pm serpantin mineralleri, minerallerinden oluştukları belirlenmiştir.
Plajiyoklaz: İnce uzun dikdörtgen şekilli kristaller halinde olup, gabroların baskın mineralini oluştururlar. Dikdörtgen şekilli kristaller birbirlerini engellemeli olarak keser konumda görülürler. I. nikolde kahverengimsi renkte ve kumsu yapıda görülen plajiyoklazlarda killeşme, sossüritleşme türü bozunmalar yaygındır (Şekil 3a). II. nikolde polisentetik, karlsbad 
türü ikizlenme gösterirler (Şekil 3b). Ancak bozunma nedeni ile sönme açısı tayini yapılamamıştır.

Piroksen: Plajiyoklaz minerallerinden sonra tüm kesitlerde en fazla görülen mineraldir. Plajiyoklaz kristalleri arasında kalan poligonal boşluklarda ince-uzun yarı özekilli-özşekilsiz kristaller halinde görülürler (Şekil 3c, d). I. nikolde yüksek röliyefe sahip olup, soluk sarımsı yeşil-yeşil renkli hafif-kuvvetli pleokroizma gösterirler. Piroksen minerallerinin birçoğunda uralitleşme, kloritleşme, aktinolit-tremolitleşme ve rodenjitleşme türünden bozunmalar yaygındır (Şekil 3e, f). Bir yönde ince dilinim çizgilerine sahiptirler. Bir yönlü dilinim izleri boyunca iğnemsi kristaller (Aktinolit-Tremolit) halinde ayrılmalar gösterirler. İri piroksen kristallerinde deformasyon sonucu oluşmuş kink-bant yapıları görülmektedir (Şekil 3g).

Amfibol: Piroksen minerallerinin uralitleşmesi, aktinolit-tremolitle dönüşmesi sonucu oluşmuşlardır. I nikolde mavimsi-yeşil renkli pleokroizma gösterirler. Piroksen minerallerinin kırık ve çatlakları boyunca magmatik ve ikincil olmak üzere iki tür uralitleşme görülmektedir (Şekil 3e). Bunun dişında ince iğnemsi kristaller eklinde, I nikolde renksiz-kahverengi renkli, yüksek röliyefe sahip aktinolit-tremolit türü amfibol oluşumları görülmektedir (Şekil 3f).

Klorit: Piroksenlerin ayrışma ürünü olarak ve/veya kristal agregatları halinde görülürler. Piroksenlerin kırık ve çatlakları boyunca gelişen ayrışma ürünü kloritler I. nikolde soluk yeşil renkte hafif bir pleokroizma gösterirler. II. Nikolde I. dizinin gri, siyah ve lacivert polarizasyon renklerini gösterirler (Şekil 3f, g). Kristal agregatları şeklinde görülen kloritler (penin) II. nikolde koyu lacivert-morumsu mavi polarizasyon renkleri ile karakteristiktir.

$\mathrm{Fe}$-Ti Oksit: Başlica ilmenit ve manyetit türündendir. İlmenit türünden olanlar tipik olarak iskelet yapısı gösterirler (Şekil 3e, h). Manyetit çoğunlukla köşeli ve/veya yuvarlağımsı kristaller halinde görülür.

Titanit: I. nikolde kahverengi renkli, yüksek röliyefe sahiptir. Çoğunlukla titanyumlu minerallerin ayrışma ürünü olarak (lökoksen) görülmektedir (Şekil 3h)

Epidot: Piroksen minerallerinin ayrışma ürünü olarak yuvarlaklaşmış özşekilsiz taneler şeklinde ve kloritle birlikte görülür. II. nikolde II. dizinin canlı girişim renkleri gösterir.

\subsection{X-Ray Difraktometre (XRD) İncelemeleri}

Gabro örneklerinde mikroskop çalışmaları sırasında belirlenemeyen daha küçük boyutlu mineral fazlarını belirleyebilmek için toplam 4 adet kayaç örneği toz haline getirilmiş, X-Işınları Difraktometre (XRD) ile analizleri yapılmıştır. Tüm kayaç toz XRD sonuçlarına göre, örneklerde plajiyoklaz (labradorit), piroksen (ojit), amfibol (aktinolit, tremolit), klorit, ilmenit, manyetit ve titanit pikleri tespit edilmiştir. Gabro örneklerinin XRD grafiklerinin tümünde düzenli ve belirgin mineral pikleri görülmektedir. Ancak bazı mineral piklerinin birbirini örttüğü ve kısmen de olsa XRD grafiklerinde düzensiz piklerin görülmesine neden olmaktadır (Şekil 4). Bu durum gabro örneklerini oluşturan ve mikroskop incelemelerinde ortaya konulan mineral fazlarındaki bozunmalarla ilişkilendirilmiştir.

\section{GABRO DAYKLARININ JEOKİMYASAL ÖZELLİKLERİ}

Gabro örneklerinin jeokimyasal özelliklerini belirlemek amaciyla; ana ve iz element analizleri yapılmıştır. Analiz sonuçlarının farklı diyagramlar kullanılarak yorumlaması yapılmış ve gabroları oluşturan magmanın karakteri ve kimyasal özellikleri belirlenmiştir. Gabro örneklerine ait jeokimyasal analiz sonuçları Çizelge 1'de verilmiştir.

Gabroları oluşturan magmanın karakterini belirlemek için toplam alkali (\% Na2O+ K2O)-silika (\% $\mathrm{SiO} 2$ ) diyagramı hazırlanmış, bu diyagrama yerleştirilen örneklerin alkalen-subalkalen çizgisi üzerine düştükleri belirlenmiştir (Şekil 5a). Subalkalen karakterli bir magma ürünü olan gabro örneklerimiz [16] tarafindan geliştirilen AFM diyagramında toleyitik alanda toplanmışlardır (Şekil 5b). Toleyitik magma ürünü olan gabrolar [17] tarafindan oluşturulan (\% Na2O+ K2O)silika $(\% \mathrm{SiO} 2)$ kayaç adlandırma diyagramında gabro alanına düşmüştür (Şekil 5c). Alterasyon, metamorfizma ve metosomatizma gibi kimyasal olaylara karşı duraylı oldukları bilinen $\mathrm{Zr}$, $\mathrm{Nb}, \mathrm{Y}$, TiO2 gibi elementler kayaçların adlandırılmasında, petrolojik özelliklerinin ve tektonik oluşum ortamlarının belirlenmesinde sıklıkla kullanılmaktadır [18]. $\mathrm{Zr}$ ve $\mathrm{TiO} 2$ elementlerinden yararlanılarak oluşturulan $\mathrm{Zr} \quad(\mathrm{ppm})-\mathrm{TiO} 2 \quad(\%)$ diyagramında, gabro örnekleri mafik/ultramafik kayaçlar alanına düşmüştür [19] (Şekil 5d). 


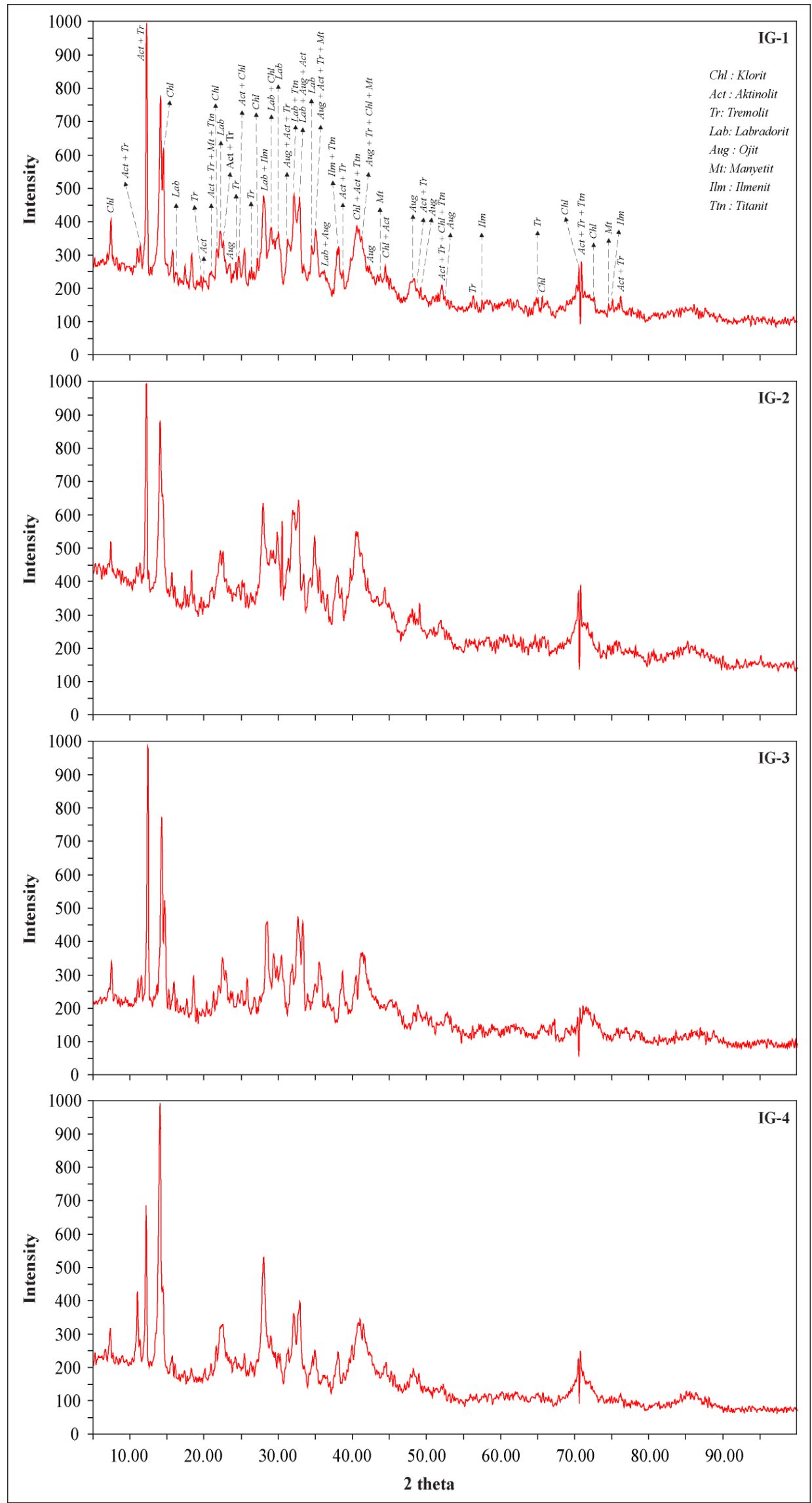

Şekil 4 Gabro örneklerine ait XRD grafikleri 
Çizelge 1 Gabro örneklerinin ana oksit ve bazı iz element kimyasal analiz sonuçları

\begin{tabular}{|c|c|c|c|c|c|c|c|c|}
\hline \multirow{2}{*}{ Element } & \multicolumn{8}{|c|}{ ÖRNEK NO } \\
\hline & TIG-1 & TIG-2 & TIG-3 & TIG-4 & TIG-5 & TIG-6 & TIG-7 & TIG-8 \\
\hline $\mathrm{Na}_{2} \mathrm{O}(\%)$ & 3,60 & 3,42 & 3,55 & 3,76 & 3,31 & 3,45 & 3,32 & 3,00 \\
\hline $\operatorname{MgO}(\%)$ & 6,99 & 7,17 & 7,35 & 7,36 & 7,37 & 7,33 & 7,25 & 6,56 \\
\hline $\mathrm{Al}_{2} \mathrm{O}_{3}(\%)$ & 15,02 & 15,71 & 15,40 & 14,98 & 15,22 & 14,82 & 15,13 & 14,38 \\
\hline $\mathrm{SiO}_{2}(\%)$ & 45,71 & 45,51 & 47,03 & 47,03 & 46,05 & 46,91 & 47,12 & 45,69 \\
\hline $\mathrm{P}_{2} \mathrm{O}_{5}(\%)$ & 0,14 & 0,12 & 0,13 & 0,13 & 0,13 & 0,14 & 0,14 & 0,13 \\
\hline $\mathrm{SO}_{3}(\%)$ & 0,31 & 0,02 & 0,25 & 0,28 & 0,23 & 0,33 & 0,37 & 0,12 \\
\hline $\mathrm{K}_{2} \mathrm{O}(\%)$ & 0,17 & 0,15 & 0,15 & 0,16 & 0,18 & 0,24 & 0,27 & 0,19 \\
\hline $\mathrm{CaO}(\%)$ & 10,92 & 11,90 & 11,19 & 10,90 & 11,03 & 10,70 & 11,01 & 10,94 \\
\hline $\mathrm{TiO}_{2}(\%)$ & 1,09 & 0,82 & 1,04 & 0,97 & 0,92 & 1,09 & 1,04 & 1,06 \\
\hline $\operatorname{MnO}(\%)$ & 0,17 & 0,16 & 0,17 & 0,17 & 0,16 & 0,18 & 0,16 & 0,17 \\
\hline $\mathrm{Fe}_{2} \mathrm{O}_{3}(\%)$ & 10,58 & 9,64 & 9,98 & 9,96 & 9,75 & 10,92 & 9,97 & 10,53 \\
\hline LOI (\%) & 4,87 & 4,68 & 3,22 & 3,75 & 3,89 & 3,61 & 2,44 & 5,39 \\
\hline Toplam & 99,59 & 99,31 & 99,47 & 99,45 & 98,26 & 99,74 & 98,22 & 98,18 \\
\hline V (ppm) & 292,5 & 262,7 & 293,1 & 290,5 & 277,9 & 310,0 & 281,2 & 311,7 \\
\hline $\mathrm{Cr}(\mathbf{p p m})$ & 114,9 & 79,4 & 134,7 & 137,7 & 119,2 & 116,3 & 132,1 & 97,8 \\
\hline Co (ppm) & 53,6 & 49,0 & 48,9 & 43,9 & 44,4 & 46,1 & 46,8 & 45,7 \\
\hline Ni (ppm) & 64,1 & 63,5 & 70,5 & 73,8 & 70,4 & 62,0 & 73,5 & 54,3 \\
\hline $\mathrm{Cu}(\mathbf{p p m})$ & 53,5 & 44,3 & 67,1 & 75,0 & 72,0 & 49,3 & 67,8 & 97,5 \\
\hline Zn (ppm) & 68,1 & 68,6 & 65,6 & 60,9 & 63,3 & 68,1 & 65,1 & 67,5 \\
\hline Ga (ppm) & 15,1 & 13,2 & 14,3 & 14,2 & 13,4 & 14,1 & 13,9 & 14,0 \\
\hline Rb (ppm) & 3,8 & 3,6 & 3,2 & 3,7 & 2,9 & 4,0 & 5,5 & 3,3 \\
\hline $\mathrm{Sr}(\mathbf{p p m})$ & 174,9 & 188,8 & 146,6 & 137,4 & 157,9 & 153,6 & 113,9 & 173,6 \\
\hline $\mathbf{Y}(\mathbf{p p m})$ & 22,8 & 18,9 & 22,6 & 20,7 & 20,4 & 22,8 & 21,9 & 23,0 \\
\hline $\mathrm{Zr}(\mathbf{p p m})$ & 56,8 & 45,2 & 58,2 & 55,3 & 51,7 & 58,3 & 56,6 & 60,2 \\
\hline Hf (ppm) & 4,1 & 4,4 & 3,9 & 3,1 & 2,8 & 1,6 & 1,9 & 2,1 \\
\hline Nb (ppm) & 2,1 & 1,9 & 1,0 & 1,2 & 1,0 & 1,6 & 1,0 & 1,3 \\
\hline Sn (ppm) & 12,5 & 9,0 & 14,4 & 14,0 & 15,3 & 13,8 & 9,8 & 15,3 \\
\hline Ba (ppm) & 12,0 & 35,1 & 14,8 & 2,9 & 51,1 & 81,1 & 2,0 & 48,4 \\
\hline Pb (ppm) & 1,6 & 1,4 & 2,2 & 0,8 & 0,9 & 0,6 & 0,9 & 1,8 \\
\hline Th (ppm) & 1,4 & 1,3 & 2,3 & 1,0 & 1,0 & 0,4 & 1,1 & 1,0 \\
\hline La (ppm) & 2,0 & 2,0 & 2,0 & 2,0 & 2,0 & 2,0 & 2,0 & 2,0 \\
\hline Ta (ppm) & 1,0 & 1,0 & 1,0 & 1,0 & 1,6 & 3,1 & 1,0 & 1,0 \\
\hline
\end{tabular}



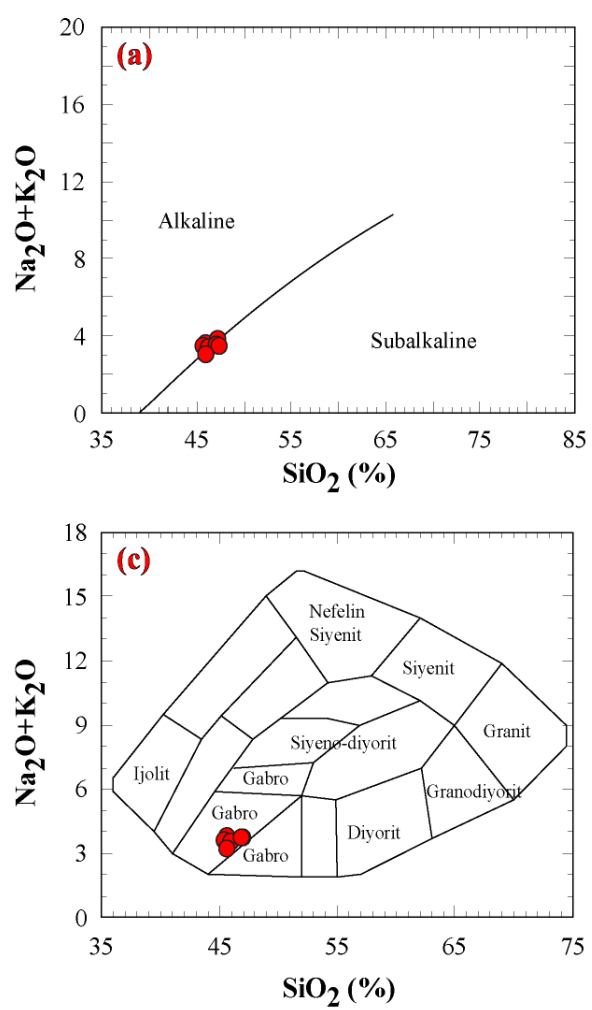
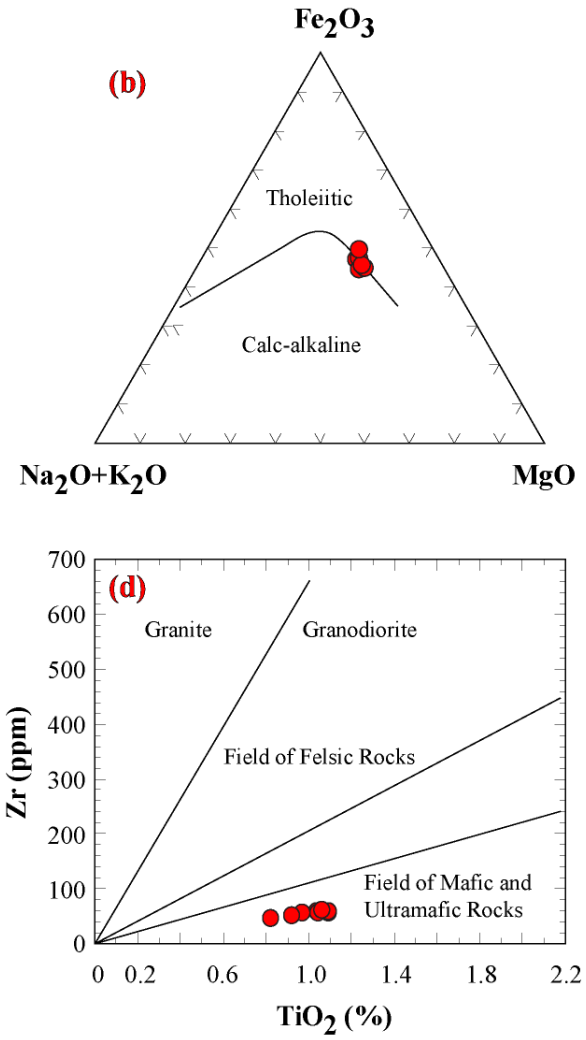

Şekil 5 İncelenen gabro örneklerinin a) $\mathrm{SiO}_{2}(\%)-\mathrm{Na}_{2} \mathrm{O}+\mathrm{K}_{2} \mathrm{O}(\%)$ [20], b) AFM (toleyitik-kalkalkalen ayrım çizgisi [16]'a göredir), c) $\mathrm{SiO}_{2}(\%)-\mathrm{K}_{2} \mathrm{O}+\mathrm{Na}_{2} \mathrm{O}(\%)$ [17], d) $\mathrm{Zr}$ (ppm)- $\mathrm{TiO}_{2}(\%)$ [19] diyagramlarındaki konumları

\subsection{Gabro Dayklarinin Ayrişma İndeksleri}

Demiryollarında balast malzemesi olarak kullanılacak kayaçların, kötü atmosfer şartlarına uzun süre dayanabilmesi, belli bir dönem sonra kolaylıkla ayrışmaması istenilmektedir. Ayrışma süreçleri boyunca kayaç ve/veya mineral kimyasında önemli değişiklikler meydana gelebilmektedir. Bu değişimler sırasında kayaç ve/veya mineral içerisindeki $\mathrm{Na}, \mathrm{Ca}, \mathrm{Mg}, \mathrm{K}, \mathrm{Si}, \mathrm{Fe}, \mathrm{Al}$ gibi elementler sıralı şekilde ortamdan uzaklaştırılmaktadır.

Kayaçların kimyasal analiz sonuçları kullanılarak farklı araştırmacılar tarafından değişik ayrışma indeksleri geliştirilmiştir. Kimyasal analizleri yapılan gabro örneklerinin Çizelge 2'de verilen eşitliklere göre indeks değerleri hesaplanmış, sonuçlar Çizelge 3 'de verilmiştir.

Ruxton Oranı (RR), [21] tarafindan çoğunlukla asidik ve ortaç bileşimli magmatik kayaçlar için önerilen basit bir ayrışma indeksidir. RR kayaç içerisindeki silika kaybına karşı toplam element kaybı ile ilişskili olup, ayrışma sürecinde alüminyum' un hareketsiz olduğunu kabul eder. Ayrışmamış bir kayaç için RR değeri $>10$ olup, bu değer ayrışma derecesinin artmasıyla birlikte azalım göstermektedir. Gabro örneklerinin RR değerleri 4.92-5.39 arasinda olup, [26]' de verilen ortalama gabro kayacına ait RR değeriyle uyumludur.
Parker İndeksi (WIP), magmatik/metamorfik kayaçların ayrışma şiddetini değerlendirmede kullanılmaktadır. WIP değerleri kayaç içerisindeki alkali ve toprak alkali (sodyum, potasyum, magnezyum ve kalsiyum) elementlerin oranlarına dayanmaktadır. Düşük WIP değerleri şiddetli kimyasal ayrışmaya işaret ederken, yüksek WIP değerleri kayacın ayrışmamış olduğunu göstermektedir [28]. İncelenen gabro örneklerinin WIP değerleri 41.58-46,55 arasında olup, [26]' de verilen ortalama gabro kayacına ait WIP değeriyle uyumludur. Magmatik kayaçlarda WIP değeri 0 - 100 arasında değişim göstermektedir [27].

Kimyasal Alterasyon İndeksi (CIA), ilk defa 1982 yılında [23] tarafindan Huronian süpergrubu erken Proterozoyik çökelleri paleoiklim özelliklerini belirlemek için önerilmiştir. CIA kayaçların kimyasal ayrışma derecesini belirlemede yaygın olarak kullanılmaktadır. Genel olarak, CIA, feldispat minerallerinin kil minerallerine dönüşümünün bir ölçüsü olarak yorumlanır ve CIA değerleri kayaç içerisindeki kil minerallerinin artışına paralel olarak artış göstermektedir [27, 28]. Gabro örneklerinin CIA değerleri 50.27-51.17 arasında değişimekte olup, [26]' de verilen ortalama gabro kayacına ait CIA değeriyle benzerlik göstermektedir. CIA değeri ayrışma göstermeyen magmatik kayaçlarda 50'nin altındadır [27, 29]. 
[24] tarfindan önerilen Kimyasal Ayrışma İndeksi (CIW) aynı zamanda ACN oranı olarak da tanımlanır. CIW değerleri ile CIA değerleri arasında büyük oranda benzerlik ve uyum görülmektedir. Ayrıșmış olsun ya da olmasın K-feldispat bakımından zengin kayaçlarda Kfeldispatlarla ilişkili $\mathrm{A} 12 \mathrm{O} 3$ değerlerinin yüksek olabileceği için, CIW değerleri hesaplanırken K2O değerleri kulanılmamaktadır [30]. Magmatik kayaçlarda CIW değeri $\leq 50-100$ arasında değişim göstermektedir [27]. Gabro örneklerinin CIW değerleri 50.54-51.49 arasında değişimektedir.

[25] tarafından Kimyasal Ayrışma İndeksi (CIW)' ne alternatif olarak Plajiyoklaz Alterasyon İndeksi (PIA) önerilmiştir. Bütün magmatik ve metamorfik kayaçların ana bileşenlerinden olan plajiyoklaz mineralleri ayrışma süreçleri boyunca göreceli olarak kolaylıkla çözünebilmekte ve kil minerallerine dönüşebilmektedir. $\mathrm{Bu}$ nedenle kayaçların ayrışma derecesinin değerlendirilmesinde rahatlıkla kullanılabilir. Gabro örneklerinin PIA değerleri 50.27-51.18 arasındadır. Ayrışmamış magmatik/metamorfik kayaçlarda PIA değeri $\leq 50$ olup, ayrışma değerinin artması ile birlikte bu değer artış göstermektedir [27].Gabro örneklerinin ait kızdırma kaybı (LOI = Lost On Ignition) \%2.44-5.39 değerleri arasındadır. Kızdırma kaybı değeri kayacın bozunma derecesiyle doğru orantılıdır. Gabro örneklerinin LOI değerlerinin nispeten yüksek olması kısmen ayrışmış olduklarını göstermektedir.

Hesaplanan ayrışma indeks değerleri ile farklı araştırmacılar tarafından verilen sınır değerleri karşılaştırıldığında incelenen gabro örneklerinin çok hafif derecede ayrışmış kaya özelliği gösterdiği söylenebilir. $\mathrm{Bu}$ amaçla hazırlanan ACNK üçgen diyagramında gabro örnekleri ACN çizgisi üzerinde yer aldığı ve CIA değerlerine göre ayrışmamış taze kaya ile hafif ayrışmış kaya ayrım çizgisi üzerine düştüğü belirlenmiştir (Şekil 6).

\section{GABRO DAYKLARININ FIZIKKO MEKANIKK ÖZELLIKLERİ}

Gabro örneklerinin fiziksel ve mekanik özelliklerini belirlemek amacıyla blok numunelerden parça ve karot numuneler hazırlanmış, ISRM (2007)' de önerilen yöntemlere göre çeşitli kaya mekaniği deneyleri yapılmıştır [31] (Şekil 7a, b).

Çizelge 2 Silikat kayaçlarında ayrışma derecesini karakterize eden bazı ayrışma indeksleri ve formülleri

\begin{tabular}{|c|c|c|c|c|c|}
\hline $\begin{array}{l}\text { Ayrışma } \\
\text { İndeksi }\end{array}$ & Simge & Formülü & $\begin{array}{l}\text { Ayrışmamış } \\
\text { Taze } \\
\text { Kayaçtaki } \\
\text { Değer }\end{array}$ & $\begin{array}{l}\text { Ayrışmış } \\
\text { Kayaçtaki } \\
\text { Değer }\end{array}$ & Kaynak \\
\hline $\begin{array}{c}\text { Ruxton oranı } \\
\text { (Ruxton } \\
\text { Ratio) } \\
\end{array}$ & $\mathbf{R R}$ & $\boldsymbol{R R}=\frac{\mathrm{mol} \mathrm{SiO}_{2}}{\mathrm{~mol} \mathrm{Al}_{2} \mathrm{O}_{3}}$ & 10 & 0 & [21] \\
\hline $\begin{array}{l}\text { Parker } \\
\text { indeksi } \\
\text { (Weathering } \\
\text { Index of } \\
\text { Parker) } \\
\end{array}$ & WIP & $\mathbf{W I P}=100 \times\left(\frac{2 \mathrm{Na}_{2} \mathrm{O}}{0.35}+\frac{\mathrm{MgO}}{0.9}+\frac{2 \mathrm{~K}_{2} \mathrm{O}}{0.25}+\frac{\mathrm{CaO}}{0.7}\right)$ & $>100$ & 0 & [22] \\
\hline $\begin{array}{c}\text { Kimyasal } \\
\text { alterasyon } \\
\text { indeksi } \\
\text { (Chemical } \\
\text { Alteration } \\
\text { Index) } \\
\end{array}$ & CIA & $\mathrm{CI} \boldsymbol{A}=100 \times\left(\frac{\mathrm{Al}_{2} \mathrm{O}_{3}}{\mathrm{Al}_{2} \mathrm{O}_{3}+\mathrm{CaO}+\mathrm{Na}_{2} \mathrm{O}+\mathrm{K}_{2} \mathrm{O}}\right)$ & $\leq 50$ & 100 & [23] \\
\hline $\begin{array}{c}\text { Kimyasal } \\
\text { ayrişma } \\
\text { indeksi } \\
\text { (Chemical } \\
\text { Index of } \\
\text { Weathering) }\end{array}$ & CIW & $\mathrm{CIW}=100 \times\left(\frac{\mathrm{Al}_{2} \mathrm{O}_{3}}{\mathrm{Al}_{2} \mathrm{O}_{3}+\mathrm{CaO}+\mathrm{Na}_{2} \mathrm{O}}\right)$ & $\leq 50$ & 100 & [24] \\
\hline $\begin{array}{c}\text { Plajiyoklaz } \\
\text { Alterasyon } \\
\text { indeksi } \\
\text { (Plagioclase } \\
\text { Index of } \\
\text { Alteration) }\end{array}$ & PIA & $P I A=100 \times\left(\frac{\left(\mathrm{Al}_{2} \mathrm{O}_{3}-\mathrm{K}_{2} \mathrm{O}\right)}{\mathrm{Al}_{2} \mathrm{O}_{3}+\mathrm{CaO}+\mathrm{Na}_{2} \mathrm{O}-\mathrm{K}_{2} \mathrm{O}}\right)$ & $\leq 50$ & 100 & [25] \\
\hline
\end{tabular}

Çizelge 3 Gabro örneklerinin hesaplanan ayrışma indeks değerleri 


\begin{tabular}{|c|c|c|c|c|c|c|}
\hline Örnek No & RR & WIP & CIA & CIW & PIA & LOI \\
\hline TIG-1 & 5,16 & 45,31 & 50,56 & 50,85 & 50,57 & 4,87 \\
\hline TIG-2 & 4,92 & 45,71 & 50,39 & 50,63 & 50,39 & 4,68 \\
\hline TIG-3 & 5,18 & 45,66 & 50,84 & 51,09 & 50,84 & 3,22 \\
\hline TIG-4 & 5,33 & 46,55 & 50,27 & 50,54 & 50,27 & 3,75 \\
\hline TIG-5 & 5,14 & 44,33 & 51,17 & 51,49 & 51,18 & 3,89 \\
\hline TIG-6 & 5,37 & 45,07 & 50,73 & 51,16 & 50,75 & 3,61 \\
\hline TIG-7 & 5,29 & 44,88 & 50,90 & 51,36 & 50,91 & 2,44 \\
\hline TIG-8 & 5,39 & 41,58 & 50,44 & 50,77 & 50,44 & 5,39 \\
\hline Gabro* & 5,45 & 44,50 & 54,43 & 56,28 & 54,74 & - \\
\hline
\end{tabular}

*[26]' de verilen 1451 analiz sonucuna göre bir gabro kayacının ortalama kimyasal bileşimdir.

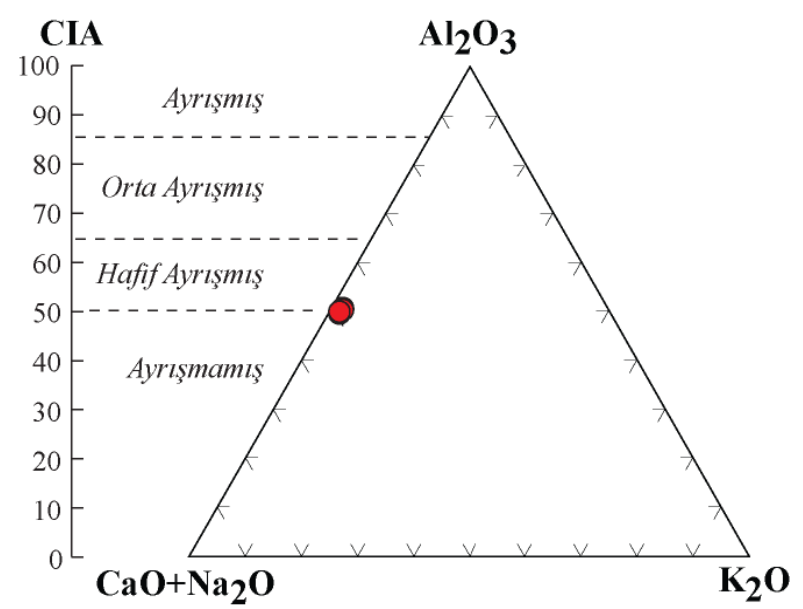

Şekil 6. İncelenen gabro örneklerinin $\mathrm{Al}_{2} \mathrm{O}_{3}-\left(\mathrm{CaO}+\mathrm{Na}_{2} \mathrm{O}\right)-\mathrm{K}_{2} \mathrm{O}$ diyagramındaki konumu (Diyagram [28]' den değiştirilerek alınmıştır)
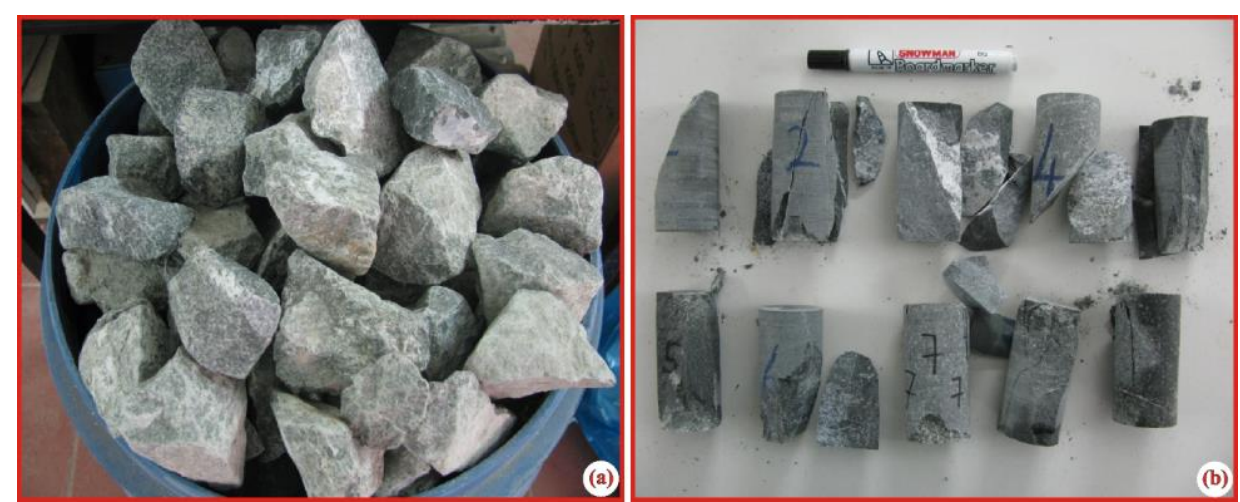

Şekil 7 Fiziksel ve mekanik deneylerin gerçekleştirildiği a) parça numunelerin, b) karot örneklerinin görünümü 


\subsection{Doğal Birim Hacim Ağırlık}

Gabro örneklerine ait birin hacim ağırlığı değerleri [32] standardına göre belirlenmiştir. $\mathrm{Bu}$ amaçla karot alıcı kullanılarak elde edilmiş silindirik deney örneklerinin çapı ve boyu, ölçüm kumpası kullanılarak birbirine dik iki ayrı yönde ölçülmüş ve bu değerlerin ortalaması alınmıştır. Boy ve çap değerleri kullanılarak örneğin hacmi hesaplanmıştır. Örnek hassas terazide tartılarak ağırlığı belirlenmiş ve birim hacim ağırlık değerleri hesaplanmıştır. Elde edilmiş olan değerler Çizelge 4'de gösterilmiştir. Buna göre gabro örnekleri 2.63 - $2.81 \mathrm{gr} / \mathrm{cm} 3$ değerleri arasında değişim göstermektedir.

\subsection{Ağırlıkça Su Emme Oranları}

Balast agregası olarak kullanılacak gabro örneklerinin su emme kapasitesinin belirlenmesi için atmosfer basıncında ağırlıkça su emme deneyleri yapılmıştır. Deneyler, [33] standartlarına uygun olacak şekilde yapılmıştır. Deneylerde, numunelerin kuru ve suya doygun ağırlıkları tespit edilerek su emme miktarları yüzde olarak tanımlanmıştır. Buna göre ağırlıkça su emme değerleri \% 0.05 - \% 0.52 değerleri arasında değişmektedir (Çizelge 5). Ortalama değer ise $\% 0.25$ olarak elde edilmiştir.

Çizelge 4 Gabro örneklerine ait birim hacim ağırlık değerleri

\begin{tabular}{|c|c|c|c|}
\hline Örnek No & Hacmi $\left(\mathrm{cm}^{3}\right)$ & Ağırlı̆̆ı (gr) & $\begin{array}{c}\text { Birim Hacim } \\
\text { Ağırlığı }\left(\mathbf{g r} / \mathbf{c m}^{3}\right)\end{array}$ \\
\hline 1 & 136.734 & 384.73 & 2.81 \\
\hline 2 & 144.297 & 380.53 & 2.63 \\
\hline 3 & 130.763 & 363.87 & 2.78 \\
\hline 4 & 132.740 & 371.27 & 2.79 \\
\hline 5 & 134.412 & 378.65 & 2.81 \\
\hline 6 & 132.883 & 374.70 & 2.81 \\
\hline 7 & 130.719 & 366.56 & 2.80 \\
\hline Ortalama & & & 2.77 \\
\hline
\end{tabular}

Çizelge 5 Gabro örneklerine ait ağırlıkça su emme değerleri

\begin{tabular}{|c|c|c|c|}
\hline Örnek No & $\begin{array}{c}\text { Numunenin Su } \\
\text { İçerisindeki } \\
\text { Ăğırlı̆̆ı (gr) }\end{array}$ & $\begin{array}{c}\text { Suya Doygun } \\
\text { Ăğırlı̆̆ı (gr) }\end{array}$ & $\begin{array}{c}\text { Ăğırlıça } \\
\text { Su Emme (\%) }\end{array}$ \\
\hline 8 & 246,91 & 381,44 & 0,16 \\
\hline 9 & 215,31 & 335,45 & 0,47 \\
\hline 10 & 228,55 & 355,76 & 0,29 \\
\hline 11 & 246,77 & 381,57 & 0,18 \\
\hline 12 & 218,42 & 344,24 & 0,52 \\
\hline 13 & 241,78 & 372,68 & 0,05 \\
\hline 14 & 232,80 & 360,51 & 0,10 \\
\hline Ortalama & & & $\mathbf{0 , 2 5}$ \\
\hline
\end{tabular}

\subsection{Tek Eksenli Basma Dayanımı}

Kayaçların basınç dayanımının bulunması, hem sınıflama hem de uygunluk değerlendirmesi açısından gereklidir. Gabro örneklerinin tek eksenli basınç dayanım deneyleri [31] ve [34] deney standartlarına göre yapılmıştır. Deneyler, araziden alınmış bloklardan elde edilen BX çaplı $(44.0 \mathrm{~mm})$ karotlar üzerinde gerçekleştirilmiştir. Deneyler, kuru ve doygun koşullar için ayrı ayrı yapılmıștır. Kurtulmuş örneklerin tek eksenli sıkışma dayanımları 84.66 MPa - 134.66 MPa değerleri arasında değişirken suya doygun örneklerin sıkışma dayanımları $67.69 \mathrm{MPa}-144.32 \mathrm{MPa}$ değerleri arasında değişmiştir (Çizelge 6). Ortalama değerler olarak ele alındığında, suya doygun örneklerin sıkışma dayanımlarında \% 7.61 mertebesinde bir azalmanın olduğu belirlenmiştir. [35] tarafından kayaçların tek eksenli sıkışma dayanımlarına göre geliştirilen sınıflama çizelgesinde gabro örneklerinin orta-yüksek dayanımlı kaya sınıfında yer aldığg görülmektedir (Çizelge 7). 
Çizelge 6 Gabro örnekleri üzerinde yapılan tek eksenli sıkışma dayanımı değerlerinin kuru ve suya doygun koşullar için değişimleri

\begin{tabular}{|c|c|c|c|}
\hline Örnek & Tek Eksenli & Örnek No & Tek Eksenli \\
\hline $\mathbf{1}$ & 94,68 & $\mathbf{8}$ & 92,88 \\
\hline $\mathbf{2}$ & 122,72 & $\mathbf{9}$ & 108,85 \\
\hline $\mathbf{3}$ & 84,66 & $\mathbf{1 0}$ & 94,21 \\
\hline $\mathbf{4}$ & 101,62 & $\mathbf{1 1}$ & 67,69 \\
\hline $\mathbf{5}$ & 134,66 & $\mathbf{1 2}$ & 88,00 \\
\hline $\mathbf{6}$ & 100,00 & $\mathbf{1 3}$ & 94,32 \\
\hline $\mathbf{7}$ & 108,78 & $\mathbf{1 4}$ & 144,32 \\
\hline Ortalama & $\mathbf{1 0 6 . 7 3}$ & Ortalama & $\mathbf{9 8 . 6 1}$ \\
\hline
\end{tabular}

Çizelge 7 Tek eksenli sıkışma dayanımı değerlerine göre kayaçların sınıflandırılması [35]

\begin{tabular}{|c|c|}
\hline $\begin{array}{c}\text { Tek Eksenli Sıkışma } \\
\text { Dayanımı (MPa) }\end{array}$ & Kaya Sınıfi \\
\hline$<25$ & Çok düşük dayanımlı \\
\hline $25-50$ & Düşük dayanımlı \\
\hline $50-100$ & Orta dayanımlı \\
\hline $100-200$ & Yüksek dayanımlı \\
\hline$>200$ & Çok yüksek dayanımlı \\
\hline
\end{tabular}

\subsection{Los Angeles Aşınma Direnci}

Los Angeles aşınma direnci deneyi özellikle agrega türü malzemelerde aşınmaya karşı direncin belirlenmesinde kullanılan bir deneydir. Aşınma direnci deneyinde, içerisinde çelik bilyeler bulunan ve çelikten yapılmış tambur içerisinde, belirli elek açıklıklarından belli miktarlarda malzeme konarak dakikada 30-33 devir yapacak şekilde toplam 500 devir yaptırılmıştır. Silindirik tambur içerisinde bilyeler çarparak bir miktar ufalanan malzeme 500 devir sonunda $10 \mathrm{~mm}$ 'lik elekten elenerek toplam kayıp aşağıdaki bağıntı kullanılarak belirlenmiştir.
Agregaların parçalanmaya karşı dirençleri [36] Madde 5'te belirtilen Los Angeles katsayısı cinsinden tayin edilmektedir. Los Angeles deney metodu, parçalanmaya karşı direncin tayininde referans deney metodu olarak kullanılmaktadır. Los Angeles katsayısı, belirli bir uygulama veya nihai kullanıma göre beyan edilmektedir. Agreganın aşınma direnci, agrega tanelerinin kırılganlığı ve sertliğini yansıtmaktadır. Balast agregası olarak kullanılacak agregaların standartlara göre aşınma kaybının 100 devir sonunda maksimum $\%$ 10, 500 devir sonunda ise maksimum $\% 30$ olması istenmektedir. Yapılan deney ile elde edilmiş aşınma direnci değeri \% 23.4 olarak bulunmuştur (Çizelge 8).

Çizelge 8 Los Angeles aşınma direncinde kullanılan numune miktarları

\begin{tabular}{|c|c|}
\hline Elek Göz Açıklıkları (mm) & Agrega Miktarı (gr) \\
\hline $40-25$ & 1258 \\
\hline $25-20$ & 1247 \\
\hline $20-12.5$ & 1252 \\
\hline $12.5-10$ & 1250 \\
\hline Toplam & 5007 \\
\hline $\begin{array}{c}\text { Los Angeles Aşımma Dayanımı } \\
(\%)\end{array}$ & $\mathbf{2 4 . 3}$ \\
\hline
\end{tabular}

\subsection{Sodyum Sülfat $\left(\mathrm{Na}_{2} \mathrm{SO}_{4}\right)$ Don Kaybı Deneyi}

Balast agregası olarak kullanılacak gabro örneklerinin don kaybı deneyi [37]' e göre yapılmıştır.
Don kayb1 deneyinde, su emme deneyinde kullanılan hassas terazi ve etüv ile birlikte deney çözeltisi ve numune için uygun büyüklükte kaplar, 350 gr susuz sodyum sülfat tuzunun (Na2SO4) 1 litre su içinde çözülmesiyle hazırlanan sodyum sülfat çözeltisi kullanılmıştır. Sırasıyla 40-25 mm arası (1000 g), 25-20 
$\mathrm{mm} \operatorname{aras1}(1000 \mathrm{~g}), 20-10 \mathrm{~mm}$ aras1 $(500 \mathrm{~g}), 10-5 \mathrm{~mm}$ arası (100 g) numune elenmiş, $110 \pm 5{ }^{\circ} \mathrm{C}$ sicaklıkta değişmez ağırlığa kadar kurutulmuş ve tartılmıştır (G1). Daha sonra $40-25 \mathrm{~mm}, 20-10 \mathrm{~mm}$ ve $10-5 \mathrm{~mm}$ arası üç grup numune içinde sodyum sülfat çözeltisi bulunan kovaya daldırılmıştır. Numune çözeltinin içinde bu halde 18 saat bekletilmiştir.

Daldırma süresinin sonunda, numuneler çözeltinin içinden çıkartılmış ve en fazla 4 saat süresince $110 \pm 5^{\circ} \mathrm{C}$ sıcaklıkta değişmez ağırlığa kadar kurutulmuştur. Oda sıcaklığına gelinceye kadar soğutulmuş örnekler tekrar çözelti kovasına daldırılmıştır. Daldırma ve çıkartarak kurutma işlemi toplam $5 \mathrm{kez}$ tekrarlanmıştır. 5 . tekrarlamanın sonunda, kurutulup soğutulan numune, su ile yıkanmıștır. Y1kama işlemi tamamlanınca, numune $110 \pm 5^{\circ} \mathrm{C}$ sicaklıkta değişmez ağırlığa kadar kurutulmuş ve ardından $40-25 \mathrm{~mm}$ ve $25-20 \mathrm{~mm}$ arasındaki numuneler $20 \mathrm{~mm}$ açıklığa sahip elekten, 20-10 mm arasındaki numuneler $10 \mathrm{~mm}$ ve $10-5 \mathrm{~mm}$ arasındaki numuneler $5 \mathrm{~mm}$ açıklıklı elek kullanılarak elenmiş, elek üstünde kalan kısım tartılmıştır (G2). Bu eleklerden geçen kısımlar don kaybı olarak belirtilmiştir. \% Don kaybı oranı (ad), (1)' de verilen eşitlikten hesaplanmıştır.

$$
a_{d}=\left[\left(G_{1}-G_{2}\right) / G_{1}\right] * 100(\%)
$$

$\mathrm{Bu}$ şekilde her grup için bulunan don kaybı değerlerinden (2)' de verilen eşitlik yardımıyla kayacın toplam don kaybı hesaplanmıștır.

$$
a_{d t}=0,5 a_{d 1}+0,3 a_{d 2}+0,2 a_{d 3}(\%)
$$

$\mathrm{Bu}$ eşitliklerde;

$\mathbf{a}_{\mathrm{dt}}$ : Kayacın toplam sodyum sülfat don kaybı (\%)

ad1 : 40-20 mm elekler arasındaki deney numunesinin don kaybı (\%)

$\mathbf{a}_{\mathbf{d} 2}$ : 20-10 $\mathrm{mm}$ elekler arasındaki deney numunesinin don kaybi (\%)

ad3 : 10-5 mm elekler arasindaki deney numunesinin don kayb1 (\%) değerleridir.

$\mathrm{Su}$ girdiği boşluklarda $-5{ }^{\circ} \mathrm{C}^{\prime}$ de $620 \mathrm{~kg} / \mathrm{cm} 2,-10$ ${ }^{\circ} \mathrm{C}$ ' de $1140 \mathrm{~kg} / \mathrm{cm} 2$ basınç meydana getirmektedir. Dolayısıyla don kaybı deneyi agregaların kullanım şartlarının belirlenmesi açısından da önemlidir. Deney sonucunda bulunan değerler Çizelge 9' da verilmiştir.

Deneysel çalışmalarla elde edilmiş fiziksel ve mekanik parametreler, ilgili deney standartları 1şı ğında değerlendirilmiştir. Deney standartları ve elde edişmiş deneysel çalışma verileri Çizelge 10' da sunulmuştur. Bu değerlendirmelere göre, incelenen gabro birimleri istenen sınır değerleri karşılamakta ve bu açıdan balast agregası olarak kullanılabilmektedir.

Çizelge 9 Gabro örneklerinin don kaybı deney sonuçları

\begin{tabular}{|c|c|c|c|c|c|}
\hline \multirow{2}{*}{ Örnek } & \multicolumn{4}{|c|}{ Elek Göz Açılığı (mm) } & Toplam Miktar \\
\cline { 2 - 5 } & $\mathbf{4 0 - 2 5}$ & $\mathbf{2 5 - 2 0}$ & $\mathbf{2 0 - 1 0}$ & $\mathbf{1 0 - 5}$ & \\
\hline $\mathbf{G}_{\mathbf{1}}$ (gr) & 1001 & 1003.5 & 501 & 100 & 2605.5 \\
\hline $\mathbf{G}_{\mathbf{2}}$ (gr) & 1971.7 & 490 & 98.2 & 2559.9 \\
\hline $\mathbf{a}_{\mathbf{d}}(\boldsymbol{\%})$ & 1.63 & 2.19 & 1.80 & \\
\hline $\mathbf{a}_{\text {dt }}(\boldsymbol{\%})$ & \multicolumn{5}{|c|}{1.83} \\
\hline
\end{tabular}

Çizelge 10 Gabroların balast agregası olarak kullanılabilirliği için gerekli fiziko-mekanik özelliklere ait sınır koșulları

\begin{tabular}{|c|c|c|c|c|}
\hline Deney Adı & $\begin{array}{c}\text { İlgili } \\
\text { Standart }\end{array}$ & $\begin{array}{c}\text { Balast Teknik } \\
\text { Sartnamesindeki } \\
\text { Sinır Değerler }\end{array}$ & $\begin{array}{c}\text { Deney } \\
\text { Verileri }\end{array}$ & Değerlendirme \\
\hline $\begin{array}{c}\text { Birim Hacim } \\
\text { Ağıllı }\end{array}$ & {$[32]$} & $>2.5 \mathrm{gr} / \mathrm{cm}^{3}$ & $\begin{array}{c}2.63-2.81 \\
\mathrm{gr} / \mathrm{cm}^{3}\end{array}$ & Uygun \\
\hline $\begin{array}{c}\text { Tek Eksenli } \\
\text { Basma Dayanımı }\end{array}$ & {$[34]$} & $>1000 \mathrm{~kg} / \mathrm{cm}^{2}$ & $\begin{array}{c}946-1346 \\
\mathrm{~kg} / \mathrm{cm}^{2}\end{array}$ & Uygun \\
\hline $\begin{array}{c}\text { Ağırlıkça Su } \\
\text { Emme Oranı }\end{array}$ & {$[33]$} & $<\% 2$ & $\% 0.52-0.05$ & Uygun \\
\hline $\begin{array}{c}\text { Los Angeles } \\
\text { Aşınma Direnci }\end{array}$ & {$[36]$} & $\begin{array}{c}500 \text { devir sonunda } \\
\text { maksimum \% } 30 \\
\text { olmalıdır. }\end{array}$ & $\% 24.5$ & Uygun \\
\hline $\begin{array}{c}\text { Sodyum Sülfatta } \\
\text { Kütle Kayb1 }\end{array}$ & {$[37]$} & $\% 10<$ & 1.83 & Uygun \\
\hline
\end{tabular}




\section{SONUÇLAR}

Demiryolu ulaşımında traversler tarafindan iletilen tüm etkileri kalıcı çökmelere uğramadan zemine ileten ve yol çerçevesine elastik bir yatak oluşturan; 30-60 mm ebadında kırılmış, keskin köșeli ve keskin kenarlı sert ve sağlam kayaçlara balast denir. Balast, demiryollarında ray altında kullanılan, yüzey suyunu ortamdan uzaklaştıran ve yük taşıyan bir malzemedir. Demiryolu yapımında balast agregası olarak kullanılacak kayaçlarda bulunması gereken özellikleri aşağıdaki şekilde özetleyebiliriz;

- Sağlam yapıda ve damarsız kayaçlar olmalıdır,

- Su geçirimliliği olmamalı, su emmesi ise düşük olmalıdır,

- Aşırı sıcak, soğuk ve yağış gibi hava etkilerine karşı dayanıklı olmalıdır,

- Çok fazla iri ve çok ufak taneli olmamalı, ideal olarak 3-6 cm çaplı tanelerden oluşmalıdır,

- Homojen olmalı, içinde toz, toprak, cüruf, ot, kök parçaları bulunmamalıdır.

Yukarıdaki özelliklerden de anlaşılabileceği gibi balast malzemesinin seçiminde jeoloji mühendisliğinin farklı disiplinlerinin (mineraloji-petrografi, jeokimya ve kaya mekaniği) birlikte çalıșması başarılı sonuçların elde edilmesine olanak sağlayacaktır. Örnek bir çalışma olan bu makalede İnceler Kasabasında (Denizli-Bozkurt) bulunan gabro ocağının mineralojik, petrografik, jeokimyasal ile mühendislik özellikleri, saha ve laboratuvar çalışmaları 1şığında ortaya konulmuş, sonuçlar aşağıda maddeler halinde verilmiştir.

1) Yeşilova ofiyolitlerine ait tektonit birimi içerisine sokulum yapmış gabro daykları arazide yeşil, yeşilimsi-gri renkli ve ince-orta $(100 \mu \mathrm{m}-2 \mathrm{~mm})$ kristalli yapıda görülmektedir. Kristal bileşenler çıplak gözle ve lupla kolaylıkla tanımlanabilmektedir.

2) Harzburjit bileşimli ultramafik kayaçlara sokulum yapmış olan gabro daykları topoğrafyada sert çıkıntılar oluşturmaktadır. Gabro dayklar bol kırıklı ve çatlaklı bir yapıda olup, kırık hatları boyunca beyaz renkli prehnit, manyezit ve opal oluşumları yaygın olarak görülmektedir.

3) Gabro dayklarından alınan örneklerin holokristalin tanesel ve/veya subofitik doku gösterdikleri ve plajiyoklaz, piroksen, amfibol, Fe-Ti oksit (ilmenit, manyetit), klorit, sfen, prehnit, manyezit \pm kalıntı olivin ve \pm serpantin mineralleri, minerallerinden oluştukları belirlenmiştir. $\mathrm{Bu}$ mineralojik bileşim yapılan XRD çalışmaları ile desteklenmektedir.
4) Optik mikroskop çalışmaları sırasında gabro örneklerini oluşturan plajiyoklaz minerallerinde killeşme ve sossüritleşme; piroksen minerallerinde uralitleşme, kloritleşme, aktinolit-tremolitleşme ve rodenjitleşme türü bozunmalar belirlenmiştir. Ancak belirlenen bozunma türleri kayacı bütün mineralojik ve dokusal özelliklerini değiştirecek kadar yaygın değildir.

5) Jeokimyasal özelliklerine toleyitik magma ürünü olan gabrolar Cox vd. (1979) tarafindan oluşturulan (\% $\mathrm{Na} 2 \mathrm{O}+\mathrm{K} 2 \mathrm{O})$-silika (\%SiO2) kayaç adlandırma diyagramında gabro alanına düşmüştür.

6) Farklı araştırmacılar tarafından önerilen ayrışma indeks değerlerine göre incelenen gabro örneklerinin çok hafif derecede ayrışmış kaya özelliği gösterdiği belirlenmiştir. Ayrıca gabro örneklerinin ayrışma indeks değerleri, [26]' de verilen ortalama gabro kayacına ait ayrışma indeks değerleri ile büyük oranda benzerlik göstermektedir.

7) Gabro örnekleri üzerinde ait yapılan deneysel çalışmalara göre kayaçların birim hacim ağırlıklarının 2.63 - $2.81 \mathrm{gr} / \mathrm{cm} 3$, ağırlıkça su emme değerlerinin \% $0.05-0.52$, tek eksenli sıkışma dayanımlarının ise kuru koşulda $84.66 \mathrm{MPa}-134.66$ MPa değerleri arasında, suya doygun koşulda ise 67.69 $\mathrm{MPa}$ - $144.32 \mathrm{MPa}$ değerleri arasında değişmekte olduğu belirlenmiştir Elde edilen deney sonuçları TSE Standartları ile karşılaştırıldığında, gabro örneklerinin tüm fiziko-mekanik özelliklerinin balast malzemesi olarak kullanılabilirlik sınırları içerisinde kaldığı görülmektedir. Ayrıca Devlet Demir Yolları tarafindan yayınlanan balast teknik şartnamesine göre incelenen gabroların balast agregası olarak kullanılabilir özelliklerde olduğu tespit edilmiştir.

\section{KAYNAKLAR}

[1]. Bilgin, Z.R., Karaman, T., Öztürk, T., Şen, M.A., Demirci, A.R., Yeşilova-Acıgöl civarının jeolojisi; MTA Raporu; No:9071; Ankara, 1990.

[2]. Şenel, M., 1/100.000 ölçekli Türkiye jeoloji haritası Denizli K9 paftası; MTA Yayınları; No:16; Ankara, 1997.

[3]. Şenel, M., Akdeniz, N., Öztürk, E.M., Özdemir, T., Kadınkız, G., Yüksel, M., Öcal, H., Serdaroğlu, M. ve Örçen, S., Fethiye (Muğla) Kalkan (Antalya) ve kuzeyinin jeolojisi; MTA Raporu; No: 9761; Ankara (yayımlanmamış), 1994.

[4]. Özpınar, Y., İğdir Köyü (Yeşilova-Burdur) Çevresindeki Ofiyolitler ve Bunlarla İlişkili 
Metamorfik Kayaçların Petrografik İncelemesi. Ç.Ü. Jeoloji Eğitiminde 20. Yıl Sempozyumu Bildiri Özetleri, 41-43s., 1997.

[5]. Çelik, Ö.F. and Delaloye, M., Origin of metamorphic soles and their post kinematic mafic dyke swarms in the Antalya and Lycian ophiolites, SW Turkey; Geological Journal; Volume: 38, Pages: 235-256, 2003.

[6]. Sarp, H., Etude Geologique et Petroraphique du cortage ophiolitique de la region situee au NordQest de Yeşilova (Burdur-Turquie); These No. 1731; Univ. Geneve. 377 p., 1976.

[7]. Karaman, T., Yeşilova - Tefenni (BURDUR) Batısında Kalan Alanın Jeolojisi ve Petrografisi; S.Ü. Fen Bilimleri Enstitüsü; Yüksek Lisans Tezi; 84 s; Konya, 1987.

[8]. Koralay, T., Niyazlar Köyü (Yeşilova-Burdur) ile Tefenni Yaylası (Tefenni-Burdur) Ofiyolitlerinin Jeolojik, Petrografik ve Petrokimyasal İncelemesi; Pamukkale Üniversitesi; Fen Bilimleri Enstitüsü; Yüksek Lisans Tezi; 145s; Denizli, 2000.

[9]. Çelik, Ö.F. and Chiaradia, M., Geochemical and petrological aspects of dike intrusions in the Lycian ophiolites (SW Turkey): a case study for the dike emplacement along the Tauride Belt Ophiolites; International Journal of Earth Sciences, Volume: 97, Pages: 1151-1164, 2008.

[10]. Poisson, A., Recherches Geologique dans les Taurides. Occidentales (Turquie); These; Univ. Paris-Sud, Orsay; 795 p; 1977.

[11]. Göktaş, F., Çakmakoğlu, A., Tarı, E., Sütçü, Y.F. ve Sarıkaya, H., Çivril- Çardak arasının jeolojisi; MTA Raporu; No: 8701 (yayınlanmamış); Ankara, 1989.

[12]. Pekuz, Ü., Acıgöl (Denizli) Playa Göl Havzasındaki Güncel Göl Tortullarının Sedimantolojisi ve Mineralojisi; CBÜ Soma Meslek Yüksekokulu Teknik Bilimler Dergisi; Cilt: 2; Sayı: 14; 56-75s., 2010.

[13]. Kazancı, N., Boyraz, S., Özkul, M., Alçiçek, M.C. and Kadıoğlu, Y.K., Late Holocene terrestrial tephra record at western Anatolia, Turkey: possible evidence of an explosive eruption outside Santorini in the eastern Mediterranean; Global and Planetary Change; Volume: 80; Pages: 36-50; 2012.

[14]. Toker, E., Akkiraz, M.S., Yağmurlu, F., Akgün, F. and Örçen, S., Sedimentary Properties of the Middle-Upper Eocene Formations in Çardak, Burdur and İncesu, SW Turkey; Turkish J Earth Sci.; Volume: 21; Pages: 335-373; 2012.
[15]. Helvac1, C., Alçiçek, M.C., Gündoğan, İ. and Gemici, Ü., Tectonosedimentary development and palaeoenvironmental changes in the Acıgöl shallow-perennial playa-lake basin, SW Anatolia, Turkey; Turkish J Earth Sci.; Volume: 22; Pages: 173-190; 2013.

[16]. Irvine, T.N. and Baragar, W.R.A., A guide to the chemical classification of the common volcanic rocks; Can. J. Earth Sci.; Volume:8; Pages:523548; 1971.

[17]. Cox, K.G., Bell, J.D. and Pankhurst, R.J., The Interpretation of Igneous Rocks; George, Allen and Unwin; 450p; London, 1979.

[18]. Rollinson, H.R., Using geochemical data: Evaluation, presentation, interpretation; John Wiley \& Sons Inc.; 352p; New York, 1993.

[19]. Hallberg, J.A. Geology and mineral deposits of the Leonora-Laverton area, northeastern Yilgam block, Western Australia; Hesperian Press; 140 p; Perth, Western Australia, 1985.

[20]. Le Maitre, R.W., Bateman, P., Dudex, A., Keller, J., Lameyre Le Bas, M.J., Sabine, P.A., Schmid, R., Sorensen, H., Streckeisen, A., Wooley, A.R. and Zanettin, B., A classification of igneous rocks and glossary of terms: Recommendations of the IUGS subcommission on the systematics of igneous rocks; Blackwell Scientific Publications Ltd.; 193p; Oxford, 1989.

[21]. Ruxton, B.P., Measures of the degree of chemical weathering of rocks; Journal of Geology; Volume: 76; Pages: 518-527, 1968.

[22]. Parker, A., An index of weathering for silicate rocks; Geological Magazine; Volume: 107, Pages: 501-504, 1970.

[23]. Nesbitt, H.W. and Young, G.M., Early Proterozoic climates and plate motions inferred from major element chemistry of lutites; Nature; Volume: 299; Pages: 715-717, 1982.

[24]. Harnois, L., The CIW index: a new Chemical Index of Weathering; Sedimentary Geology; Volume: 55; Pages: 319-322, 1988.

[25]. Fedo, C.M., Nesbitt, H.W. and Young, G.M., Unraveling the effects of potassium metasomatism in sedimentary rocks and paleosols, with implications for paleoweathering conditions and provenance; Geology; Volume: 23, Pages: 921-924, 1995.

[26]. Blatt, H. and Tracy, R.J., Petrology: Igneous, Sedimentary and Metamorphic; 2nd edition. W.H. Freeman; 529p; New York, 1996.

[27]. Price, J. R., and Velbel, M. A., Chemical weathering indices applied to weathering profiles 
developed on heterogeneous felsic metamorphic parent rocks; Chemical Geology; Volume: 202; Pages: 397-416, 2003.

[28]. Shao, J., Yang, S. and Li, C., Chemical indices (CIA and WIP) as proxies for integrated chemical weathering in China: Inferences fromanalysis of fluvial sediments; Sedimentary Geology; Volume: 265-266; Pages 110-120, 2012.

[29]. Kontou, S., Evaluating provenance techniques in the hydrocarbon industry: Compositional quantification of modern sands from known tectonic settings as analog for the correlation of hydrocarbon bearing rocks in ancient geological settings; University of Stavanger; Master's Thesis; 56p; Norway, 2012.

[30]. Fiantis, D., Nelson, M., Shamshuddin, J., Goh, T.B. and Van Ranst, E., Determination of the Geochemical Weathering Indices and Trace Elements Content of New Volcanic Ash Deposits from Mt. Talang (West Sumatra) Indonesia; Eurasian Soil Science; Volume: 43(13); Pages: 1477-1485, 2010.

[31]. ISRM, 2007, The complete ISRM suggested methods for rock characterization, testing and monitoring: 1974-2006. In: Ulusay R, Hudson JA (eds) Suggested methods prepared by the commission on testing methods, ISRM, Compilation arranged by the ISRM Turkish National Group, Kozan ofset, Ankara

[32]. ASTM C 127-88, Test Method For Specific Gravity and Absorption of Coarse Aggregate; Annual Books of ASTM Standards Designation; C 127-88, 04.01, 64-68, 1998.

[33]. TS 699., Doğal yapı taşları - İnceleme ve laboratuvar deney yöntemleri; Türk Standartları Enstitüsü; Ankara. Mart 2009.

[34]. TS EN 1926., Doğaltaşlar-Deney metotlarıBasınç dayanımı tayini; Türk Standartları Enstitüsü; 12 s., Ankara, 2007.

[35]. Deere, D.U., Miller, R.P., Engineering classification and index properties for intact rock. Air Force Weapons Laboratory Technical Report; Volume I-II, Leonard Hill, 270 p., 1966.

[36]. TS EN 1097-2; Agregaların mekanik ve fiziksel özellikleri için deneyler, Bölüm 2: Parçalanma direncinin tayini için metotlar; Türk Standartları Enstitüsü; Ankara, 2010.

[37]. TS EN 1367-1; Agregaların 1s1 ve bozunma özelliklerinin tayini için deneyler - Bölüm 1: Donma ve çözünmeye karşı direncin tayini; Türk Standartları Enstitüsü; 11 s., Ankara, 2009 